\title{
ANALISIS TINDAK TUTUR DALAM CERAMAH KH ANWAR ZAHID
}

\author{
Nisaul Fadilah \\ MTS Jabal Noer Sidoarjo \\ Jl. Geluran, Taman, Sidoarjo, Indonesia \\ Pos-el : nisaul.fadhilah95@yahoo.com
}

\begin{abstract}
A form of communication called speech, in which have the means and a particular purpose hanging from the context of tuturan delivered. A method to this research using methods documentation. This means that data in research is taken of the document is in youtube. The data were drawn from lectures given by KH Anwar Zahid who was a kiai is using his theory of Yule. The result of this research is (1) a speech act lokusi is to follow up said meaningful as expressed in speech or meaning they are. A lokusi consisted of three types namely inform, forbids the praises of, a speech act (2) ilokusi is also said that has meaning as acknowledged by Listener. (3) a speech act perlokusi is a speech act that is big with meaning the speakers of desired. A speech act perlokusi is composed of perlokusi perform the act of, perlokusi perlokusi a feeling of anger and a feeling of delight
\end{abstract}

Keywords: a speech act , lokusi, ilokusi , perlokusi

\begin{abstract}
Abstrak
Bentuk dari komunikasi disebut tuturan, yang di dalamnya memiliki maksud dan tujuan tertentu tergantung dari konteks tuturan yang disampaikan. Metode pada penelitian ini menggunakan metode dokumentasi. Artinya data dalam penelitian ini diambil dari dokumen yang terdapat dalam you tube. Data tersebut diambil dari ceramah yang disampaikan oleh $\mathrm{KH}$. Anwar Zahid yang merupakan seorang kiai dari Bojonegoro dengan menggunakan teorinya Yule. Hasil dari penelitian ini ialah (1) tindak tutur lokusi merupakan tindak tutur yang bermakna seperti yang dinyatakan dalam ujaran atau makna apa adanya. Tindak lokusi tersebut terdiri atas tiga jenis yaitu memberi informasi, melarang serta memuji, (2) tindak tutur ilokusi merupakan tindak tutur yang memiliki makna seperti yang dipahami oleh pendengar. (3) tindak tutur perlokusi merupakan tindak tutur yang memiliki makna yang diinginkan si penutur. Tindak tutur perlokusi ini terdiri atas perlokusi melakukan tindakan, perlokusi perasaan marah serta perlokusi perasaan senang.
\end{abstract}

Kata kunci : tindak tutur, lokusi, ilokusi, perlokusi 


\section{PENDAHULUAN}

Dalam berkomunikasi manusia menggunakan bahasa. Sebagai alat berkomunikasi bahasa memiliki beberapa fungsi. Menurut Rani (2004), fungsi bahasa terdiri dari fungsi ekspresif, fungsi direktif, fungsi informasional, fungsi metalingual, fungsi interaksional, fungsi kontekstual, dan fungsi puitik.

Komunikasi bertujuan untuk mengungkapkan perasaan dan pikiran yang dapat diartikan sebagai proses penyampaian tuturan. Proses penyampaian tuturan dalam berkomunikasi ini dikatakan berhasil apabila pesan atau informasi yang ingin disampaikan dapat diterima dengan baik oleh mitra tutur atau pendengar.

Bentuk komunikasi ini disebut tuturan, yang didalamnya terdapat makna yang tersirat maupun makna yang tersurat tergantung dari konteks kalimat yang disampaikan. Karena bahasa itu bermakna, maka segala ucapan yang tidak memunyai makna dapat disebut bukan bahasa (Chaer, 2007: 45). Oleh sebab itu, dalam melakukan sebuah tuturan, tentunya tidak hanya mengucapkan serangkaian kata atau kalimat semata melainkan juga sebuah tindakan sebagai respon dari tuturan tersebut. Kegiatan inilah yang sering disebut sebagai kegiatan tindak tutur.

Tindak tutur ini juga terjadi dalam ceramah KH. Anwar Zahid. Beliau berasal dari Dukuh Patoman, Desa Simorejo, Kecamatan Kanor, Kabupaten Bojonegoro. Beliau adalah tokoh perjuangan Islam baru yang terkenal sebagai pendakwah gaul di seluruh pelosok tanah air. Ceramah beliau menjadi khas karena disampaikan dengan logat asli Jawa Timur dan memiliki gaya bicara yang lucu dan menggilitik. Gaya bicara seperti itulah yang membuat pendengar atau ribuan orang yang mendengarkan tak mau beranjak dari tempat duduknya.

Penggunaan bahasa dalam menyampaikan ceramah di depan masyarakat merupakan kegiatan berinteraksi yang terjadi antara penceramah dan pendengar untuk membahas suatu hal yang dapat bermanfaat untuk masyarakat. Penceramah selalu menggunakan bahasa untuk mempermudah dalam berkomunikasi. Pembicara dalam menyampaikan ceramahnya memiliki kecenderungan untuk menyesuaikan jenis tindak tutur yang digunakan dengan konteksnya, sehingga masyarakat yang mendengarkan dapat dengan mudah memahami tuturan yang disampaikannya. Setiap penutur atau pembicara memiliki cara tersendiri untuk mengekspresikan maksud tuturannya. Tujuannya adalah untuk mempermudah pendengar dalam menangkap maksud dari tuturan yang diungkapkan.

Penelitian ini mengacu pada konteks pragmatik. Konteks dalam ilmu pragmatik memiliki peranan 
yang penting, hal ini dikarenakan konteks memengaruhi bentuk bahasa yang akan digunakan oleh penutur atau pembicara. Suatu tuturan akan memiliki makna dan bentuk yang berbeda apabila diterapkan pada konteks yang berbeda. Misalnya, tuturan yang digunakan oleh seorang dosen dan mahasiswa di sebuah perguruan tinggi atau seorang guru dan siswa di lingkungan sekolah akan berbeda dengan tuturan yang digunakan oleh seorang penceramah dalam sebuah ceramah. Tuturan yang digunakan oleh seorang dosen dan mahasiswa di perguruan tinggi, seorang guru dan siswa di lingkungan sekolah dituntut untuk menggunakan bahasa resmi (bahasa Indonesia) dengan baik dan benar, sedangkan tuturan yang digunakan oleh penceramah dalam sebuah ceramahnya menggunakan bahasa dengan ragam santai disesuaikan dengan masyarakat pendengarnya.

Penelitian ini dilakukan untuk menemukan jenis tindak tutur, di antaranya tindak tutur lokusi, tindak tutur ilokusi serta tindak tutur perlokusi yang ada di dalam ceramah K.H.Anwar Zahid.

Berdasarkan uraian di depan, maka penelitian ini berjudul "Tindak Tutur dalam Ceramah KH. Anwar Zahid." Peneliti mengangkat judul ini, karena ceramah KH. Anwar Zahid memiliki perbedaan dengan penceramah lainnya. Perbedaan tersebut terdapat dalam penyampaian materi ceramah.

Pada umumnya penyampaian ceramah disampaikan dengan serius sebab tuturan yang disampaikan memiliki kebenaran yang hakiki. Namun dalam ceramah KH.Anwar
Zahid menjadi lebih berbeda karena penyampaian materi ceramah disampaikan dengan banyak humor sehingga mengundang tawa para pendengarnya.

Menurut Yule (2009: 82), tindak tutur merupakan tindakan-tindakan yang ditampilkan melalui tuturan. Tindak tutur merupakan gejala individual yang bersifat psikologis dan keberlangsungannya ditentukan oleh kemampuan bahasa si penutur dalam menghadapi situasi tertentu sehingga lebih kepada melihat makna atau arti tindakan dalam tuturannya (Rachmawati, 2016). Chaer (2013: 27) dalam Rahayuningsih (2013) mengatakan bahwa tindak tutur adalah tuturan dari seseorang yang bersifat psikologis dan yang dilihat dari makna tindakan dalam tuturannya itu.

Berdasarkan beberapa pendapat di depan dapat disimpulkan bahwa tindak tutur merupakan suatu tindakan-tindakan yang dihasilkan melalui tuturan. Pada setiap tuturan bukan hanya ucapan semata melainkan mengandung sebuah tindakan. Oleh karena itu saat berbicara bukan hanya menghasilkan tuturan yang berupa kalimat tetapi juga memiliki fungsi tertentu yang dapat dipahami dalam situasi tertentu. Selain itu segala tindak manusia yang dilakukan melalui lisan yang berupa tuturan juga digunakan untuk mengungkapkan pendapat, ide, saran, pujian, dukungan kritikan, maupun perasaan.

Sebuah tuturan selain menghasilkan makna juga akan menghasilkan sebuah tindakan. Hal itu tergantung penafsiran pendengar 
tuturan tersebut. Dari tindakan yang dihasilkan dari sebuah tuturan tersebut mengandung tiga tindak yang saling berhubungan. Tindak tutur tersebut antara lain sebagai berikut.

\section{a. Tindak Lokusi}

Tindak lokusi adalah tindak tutur yang menyatakan sesuatu tindak lokusi dalam hal ini dikaitkan secara langsung oleh penutur dengan bentuk ujaran secara fasih atau tepat.

Menurut Yule (2009; 8) tindak lokusi merupakan tindak dasar tuturan atau menghasilkan suatu ungkapan linguistik yang bermakna. Perhatikan contoh kalimat berikut.

"Nilai rapormu bagus sekali $n a k^{\prime \prime}$

Pada kutipan di atas disampaikan oleh orang tua kepada anaknya atau bisa juga seorang guru yang mengatakan kepada siswanya mengenai nilai rapor yang didapatkan. Tuturan tersebut bermaksud mengungkapkan rasa bangga terhadap anak tersebut mengenai nilai rapornya yang memuaskan.

Chaer (2013: 78) mengatakan yang dimaksud dengan makna lokusi adalah makna seperti yang dinyatakan dalam ujaran, makna harfiah, atau makna apa adanya. Misalnya, kalau seseorang kepada tukang afdruk foto di pinggir jalan bertanya, berapa?"

"Bang, tiga kali empat,

Makna secara lokusi kalimat tersebut adalah keinginan tahu dari si penutur tentang berapa tiga kali empat.

\section{b. Tindak Ilokusi}

Tindak ilokusi merupakan sebuah tuturan yang selain berfungsi untuk mengatakan atau menyampaikan sesuatu dapat juga digunakan untuk melakukan sesuatu. Tindak ilokusi disebut sebagai The Act of Doing Something. Tindak ilokusi merupakan tindak tutur yang paling sukar untuk pengidentifikasiannya karena terlebih dahulu mempertimbangkan siapa penutur dan lawan tutur, kapan tindak tutur itu terjadi. Dengan demikian tindak ilokusi merupakan bagian sentral untuk memahami tindak tutur (Khotimah: 2017: 13). Berikut contoh kalimat tindak ilokusi.

"Nilai rapormu bagus sekali $n a k^{\prime \prime}$

Tuturan di atas memiliki beberapa makna. Bisa jadi tuturan itu disampaikan untuk memuji seorang anak atau siswa yang mendapatkan nilai bagus. Tetapi bisa juga tuturan tersebut mengandung sindiran bahwa nilainya sangat jelek sehingga diungkapkan secara sindiran supaya nilainya diperbaiki.

Chaer (2013: 78) berpendapat bahwa yang dimaksud dengan makna ilokusi adalah makna seperti yang dipahami oleh pendengar. Perhatikan kalimat berikut. berapa?"

"Bang, tiga kali empat,

Jika si pendengar memiliki makna ilokusi bahwa si penutur ingin tahu berapa biaya mencetak foto ukuran tiga kali empat sentimeter, tentu dia akan menjawab, misalnya, "dua ribu" atau "tiga ribu". Tetapi kalau 
makna ilokusinya sama dengan makna lokusi ujaran "tiga kali empat berapa", dia pasti akan menjawab "dua belas", bukan jawaban yang lain.

\section{c. Tindak Perlokusi}

Menurut Yule (2009; 84) tindak perlokusi bergantung pada keadaan, pembicara akan menuturkan dengan asumsi bahwa pendengar akan mengenali akibat yang pembicara timbulkan (misalnya; untuk menerangkan suatu aroma yang luar biasa, atau meminta pendengar untuk minum kopi). Berikut contoh kalimat tindak ilokusi.

$n a k^{\prime \prime}$

"Nilai rapormu bagus sekali

Tuturan di atas juga memiliki tafsiran yang berbeda. Ketika tuturan tersebut dimaksudkan sebagai pujian maka akan tampak rasa bahagia karena mendapat pujian. Sebaliknya jika itu merupakan sindiran maka tampak sedih di wajah bahkan ia merasa jatuh dan tak bersemangat lagi.

Menurut Chaer (2013:78) makna perlokusi adalah makna seperti yang diinginkan oleh penutur. Berikut contoh kalimatnya. berapa?"

"Bang, tiga kali empat,

Makna perlokusinya ialah makna yang diinginkan si penutur, yakni si penutur ingin tahu berapa biaya mencetak foto ukuran tiga kali empat sentimeter.

\section{METODE PENELITIAN}

Penelitian ini menggunakan jenis penelitian kualitatif. Menurut Arikunto (2010;21), data yang diperoleh dari penelitian kualitatif ialah data yang diujudkan dalam kata keadaan atau kata sifat. Moleong (dalam Arikunto 2010;22) juga berpendapat bahwa penelitian kualitatif adalah tampilan yang berupa kata-kata lisan atau tertulis yang dicermati oleh peneliti, dan bendabenda yang diamati sampai detailnya agar dapat ditangkap makna yang tersirat dalam dokumen atau bendanya. Metode penelitian kualitatif ini sering disebut metode penelitian naturalistik karena penelitiannya dilakukan pada kondisi yang alamiah (natural setting); disebut juga sebagai metode etnographi, karena pada awalnya metode ini lebih banyak digunakan untuk penelitian bidang antropologi budaya; disebut sebagai metode kualitatif, karena data yang terkumpul dan analisisnya lebih bersifat kualitatif.

Berdasarkan ciri-ciri penelitian kualitatif data yang digunakan dalam penelitian berupa kata-kata dan kalimat yang mengandung tindak tutur lokusi, tindak tutur ilokusi, dan tindak tutur perlokusi yang terdapat dalam ceramah KH. Anwar Zahid. Jenis penelitian ini adalah deskriptif. Artinya penelitian yang digunakan untuk mendeskripsikan suatu keadaan atau fenomena. Pada penelitian ini akan diuraikan mengenai jenis penelitian tindak tutur yang berupa lokusi, ilokusi serta perlokusi yang terdapat dalam ceramah KH. Anwar Zahid. Selain itu pengambilan data dilakukan secara alamiah. Proses penganalisisan data tidak melibatkan penghitungan secara statistik.

\section{HASIL DAN PEMBAHASAN}

Di bawah ini disajikan beberapa tindak tutur, di antaranya tindak tutur 
lokusi, tindak tutur ilokusi serta tindak tutur perlokusi.

\section{Tindak Tutur Lokusi}

Chaer (2013: 78) mengatakan yang dimaksud dengan makna lokusi adalah makna seperti yang dinyatakan dalam ujaran, makna harfiah, atau makna apa adanya.

\section{Informasi}

Tindak Tutur Lokusi Memberi

Tindak tutur lokusi memberi informasi ialah tindak tutur yang bermaksud menyampaikan pendapat penutur terhadap pendengar. Tindak tutur tersebut terlihat pada kutipan berikut.

(1)“Aku tahu kok apa yang diumekin? Di antara ngumekin diriku. Gak gak GR blas. Sing wong nom-nom ngomong, sekarang tampilannya beda ya. gak ada yang berbeda dari aku. Aku masih seperti yang dulu"1I/II/LMI).

Tuturan pada data disampaikan penutur ketika para pendengar kurang memperhatikan apa yang disampaikannya. Mereka tampak sibuk sendiri-sendiri sehingga penutur beranggapan bahwa mereka sibuk memerhatikan dirinya yang terlihat berbeda penampilannya. Oleh karena itu tuturan di depan bermaksud memberi informasi bahwa penampilan si penutur tetap sama, tidak ada yang berbeda. Hal tersebut terlihat pada kalimat aku masih seperti yang dulu.

(2) "Rosulullah hijrah ke Madinah dalam perjalanan sampai di satu tempat namanya Kubah. Disitu
Rosulullah membangun masjid dan itu adalah masjid yang pertama kali dibangun dalam Islam namanya masjid $\operatorname{Kubah"~}^{\prime}$ / II/LMI)

Makna lokusi pada kutipan data (2) yaitu memberi informasi mengenai masjid Kubah. Penutur menginformasikan bahwa ketika Rosulullah hijrah ke Madinah, Rosulullah membangun masjid yang pertama kali yakni masjid Kubah.

\section{Tindak Tutur Lokusi Melarang}

Tindak tutur lokusi melarang merupakan sebuah tuturan yang disampaikan kepada pendengar dengan maksud melarang pendengar untuk tidak melakukan suatu hal seperti yang telah disampaikan penutur. Sebagaimana kutipan berikut.

(3) “Dan para sahabat secinta apapun kepada sesuatu kalau ada urusan sama Rosulullah kalah cintanya dengan Rosulullah. Santri biyen yo ngunu nek karo kiayine. Tapi sing dadi kiayi gak oleh mraktekno ngunu lo. Engkok pas santrine duwe bojo uayu dijaluk. Ini khususiah kanggo kanjeng nabi" (8I/II/LM)

Tuturan yang disampaikan penutur pada data (3) merupakan lokusi melarang. Seorang penutur melarang mitra tutur untuk tidak meniru sikap Rosulullah yang selalu menang dalam urusan cinta, sebab hal itu khusus Rosulullah. Oleh karena itu penutur melarang mitra tutur yang menjadi kiayi untuk tidak mempraktekkan meminta istri dari 
santrinya. Hal tersebut ditandai dengan kata gak oleh yang artinya melarang.

\section{Tindak Tutur Lokusi Memuji}

Tindak tutur lokusi memuji merupakan tindak tutur yang disampaikan dengan tujuan memuji atau menyanjung kehebatan seseorang atau keahlian yang dimiliki seseorang. Tindak tutur tersebut terlihat pada kutipan berikut.

(4) "Imam Ghozali, sing terkenal tokoh internasional bukan hanya dunia Islam yang mengakui kehebatannya Iman Ghozali. Non muslim pun mengakui kehebatannya Imam Ghozali ahli nulis kitab" (12/II/IEM)

Makna tuturan pada data (4) ialah penutur memuji kehebatan seorang tokoh internasional yang ahli menulis kitab yakni Imam Ghozali. Penutur mengatakan bahwa bukan hanya dunia Islam yang mengakui kehebatannya Imam Ghozali melaikan non muslim juga. Hal tersebut ditandai dengan kata mengakui kehebatannya, artinya memang benarbenar hebat sehingga tuturan tersebut merupakan ilokusi memuji.

\section{Tindak Tutur Ilokusi}

Tindak ilokusi merupakan sebuah tuturan yang selain berfungsi untuk mengatakan atau menyampaikan sesuatu dapat juga digunakan untuk melakukan sesuatu. Tindak ilokusi disebut sebagai The Act of Doing Something.

\section{Ilokusi Asertif/ Representatif}

Ilokusi asertif ialah tindak tutur yang menjelaskan apa dan bagaimana sesuatu itu adanya, misalnya pemberian pernyataan, pemberian saran, pelaporan, dan sebagainya.

\section{Ilokusi Pemberian Saran \\ Ilokusi pemberian saran merupakan sebuah tuturan yang disampaikan oleh penutur kepada pendengar dengan tujuan memberi saran untuk melakukan yang lebih baik. Tuturan tersebut terlihat pada kutipan berikut. \\ (5) "Ibuk. kalau pilih menantu cari yang agamanya kuat ya bu? Yang ahli ibadah ya bu? Yang rajin ngaji ya bu? Jangan yang kayak di sana- sana" (13/I/IRS)}

Tuturan yang disampaikan penutur pada data (5) termasuk ilokusi pemberian saran sebab dalam tuturan tersebut penutur bermaksud menyampaikan sebuah saran atau anjuran kepada mitra tutur agar memilih calon menantu yang ahli ibadah dan rajin mengaji. Dalam tuturan pemberian saran tersebut ditandai dengan kata kalau pilih menantu.
Ilokusi Bangga
Ilokusi bangga merupakan tuturan yang disampaikan oleh penutur yang memiliki makna tersirat bahwa ia merasa bangga terhadap dirinya. Ilokusi tersebut terlihat pada kutipan berikut. 
(6) “Oh iya selebriti itu. Itu kan orang-orang terkenal semua, tapi hidupnya ya usreg wae. Enaknya dimana? Saya tidak terkenal saja itu kadangkadang mau naruh ini badan susah" (17/I/IRB)

Tuturan yang disampaikan penutur pada data (6) termasuk dalam tindak tutur ilokusi membanggakan sebab dalam tuturan tersebut penutur bermaksud menyampaikan rasa bangga terhadap dirinya. Penyampaian rasa bangga tersebut ditandai dengan kalimat saya tidak terkenal saja itu kadang-kadang mau naruh ini badan susah,artinya penutur yang merasa dirinya belum terkenal namun gerak-geriknya selalu diamati masyarakat sehingga penutur merasa susah ketika akan menempatkan dirinya pada suatu tempat.

\section{Ilokusi Mengeluh}

Ilokusi mengeluh merupakan sebuah tuturan yang mengandung makna keluhan atas keadaan yang terjadi pada dirinya. Tuturan tersebut terlihat pada kutipan berikut.

(7) “Kalau disuruh mengeluh pinter-pinter. Lagi musim hujan kayak gini rumahnya bocor, cuma dua tempat yang bocor. Cuma dua tempat tapi sambate ketemu temen, mbak mbak lek tepak udanudan ngene iki toh omahku bocor kabeh. Padahal bocornya cuma dua titik" (22/I/IRM)
Tuturan pada data (7) termasuk ilokusi mengeluh karena penutur menyampaikan keluhannya mengenai rumahnya bocor semua ketika musim hujan padahal yang bocor hanya pada dua titik saja. Keluhan tersebut ditandai dengan kalimat udan-udan ngene iki toh omahku bocor kabeh.

\section{Ilokusi Menunjukkan}

Ilokusi meunjukkan merupakan sebuah tuturan yang bermaksud menunjukkan sesuatu kepada pendengar. Hal tersebut terlihat pada kutipan berikut.

(8) "Sering saya sampaikan ukuran seneng dengan adzan itu sama dengan lagi puasa Romadhon denger adzan maghrib. Seneng apa seneng? Yo ndak seneng tok adzan, wong sing ditunggu yo maghrib itu" (27/I/IRMJ)

Kutipan pada data (8) merupakan ilokusi menunjukkan sebab penutur bermaksud menunjukkan ukuran seseorang yang bahagia ketika mendengar seruan adzan, yakni ukurannya sama dengan ketika seseorang mendengar adzan maghrib saat puasa sebab orang puasa pasti menunggu saatnya berbuka.

\section{Tindak Tutur Perlokusi}

Menurut Yule (2009; 84) tindak perlokusi bergantung pada keadaan, pembicara akan menuturkan dengan 
asumsi bahwa pendengar akan mengenali akibat yang pembicara timbulkan (misalnya; untuk menerangkan suatu aroma yang luar biasa, atau meminta pendengar untuk minum kopi).

\section{Tindak Tutur Perlokusi Melakukan Tindakan}

Tindak tutur perlokusi melakukan tindakan merupakan sebuah efek atau akibat yang ditimbulkan karena sebuah tuturan yang disampaikan oleh penutur. Tuturan di bawah ini merupakan perlokusi melakukan tindakan yang ditimbulkan oleh pendengar.

(9) "koen iku lapo le munggahmunggah? Ceblok engkok. Ibuk'e nang ndi seh iki? (46/I/PT)

Kutipan pada data (9) termasuk perlokusi melakukan tindakan sebab setelah penutur mengatakan tuturan di depan, panitia segera mengambil anak tersebut dari atas panggung.

\section{Tindak Tutur Perlokusi Perasaan Marah}

Tindak tutur perlokusi perasaan marah merupakan sebuah efek atau akibat yang ditimbulkan karena sebuah tuturan yang disampaikan oleh penutur. Tuturan di bawah ini merupakan perlokusi marah yang ditimbulkan oleh pendengar.

(10) "Ayo siapa yang merasa lebih cantik dari Lady Diana?? Ngacung! Ora wani wong burekburek ngunu kok" (51/I/PPM)

Kutipan pada data (10) merupakan perlokusi perasaan marah sebab penutur membandingkan kecantikan Lady Diana dengan masyarakat setempat dan penutur meminta pendengar angkat tangan bagi yang merasa lebih cantik. Namun tak ada yang melakukan itu dan penutur mengatakan kalau masyarakat sini burek-burek, artinya cantiknya tak sebanding Lady Diana. Oleh karena itu ucapan penutur membuat masyarakat sedikit sakit hati atau marah.

\section{Tindak Tutur Perlokusi Perasaan Senang}

Tindak tutur perlokusi perasaan senang merupakan sebuah efek atau akibat yang ditimbulkan karena sebuah tuturan yang disampaikan oleh penutur. Hal tersebut terlihat pada kutipan berikut.

(11) "Coba saya nanya ibu, misalnya ibu punya anak perawan cantik kaya ibunya. Hmm bendol ndase, diilokno ayu langsung mekrok-mekrok" (53/I/PPM)

\section{Kutipan pada data} termasuk perlokusi perasaan senang sebab penutur mengatakan bahwa anak perawan itu cantik seperti ibunya. Kata cantik yang ditujukan untuk seorang wanita akan membuat hatinya merasa senang karena kata tersebut merupakan suatu pujian.

\section{Simpulan}

Pada bab ini disajikan simpulan hasil penelitian yang telah diuraikan pada di depan. Berdasarkan hasil penelitian dapat ditarik simpulan bahwa tindak tutur yang terdapat 
dalam ceramah KH. Anwar Zahid antara lain sebagai berikut.

1. Tindak Tutur Lokusi, antara lain:

a. Tindak tutur lokusi memberi informasi berisi tentang sebuah informasi hijrah Rosulullah, kemewahan dan popularitas serta pahala di Bulan Romadhon.

b. Tindak tutur lokusi melarang berisi tentang larangan untuk menyengsarakan binatang serta larangan untuk tidak meninggalkan ibadah selepas Romadhon,

c. Tindak tutur lokusi memuji berisi tentang pujian terhadap kehebatan Imam Ghazali yang ahli menulis kitab.

2. Tindak Tutur Ilokusi, antara lain:

a. Ilokusi asertif/ representatif

1) Ilokusi pemberian saran berisi tentang saran dalam memilih calon menantu, saran kepada wanita untuk merendahkan diri terhadap suami serta saran untuk mencari guru ketika ingin mengaji.

2) Ilokusi bangga berisi tentang penyampaian rasa bangga terhadap dirinya.

3) Ilokusi mengeluh berisi tentang keluhan rumah yang bocor, sandal yang hilang di masjid serta penggunaan bahasa jawa yang kurang dipahami pendengar.

4) Ilokusi menunjukkan berisi tentang bahagianya seseorang ketika mendengar adzan, menunjukkan berlipatnya pahala di bulan Romadhon.

b. Ilokusi Komisif terdapat ilokusi penolakan yang berisi tentang sebuah penolakan dari penutur untuk meneruskan ceramahnya karena waktu yang diberikan telah usai.

c. Ilokusi Direktif

1) Ilokusi meminta berisi tentang penutur yang meminta pendengar untuk memberikan kopi untuknya dan juga meminta untuk meninggalkan urusan duniawi pada waktu maghrib hingga isya'

2) Ilokusi menyuruh berisi tentang sebuah perintah kepada panitia untuk mengondisikan seorang anak yang bermain di atas panggung.

d. Ilokusi Ekspresif

1) Ilokusi memuji berisi tentang pujian kepada masyarakat atas kesabarannya dalam mengikuti pengajian.

2) Ilokusi meminta maaf berisi tentang permohonan maaf apabila ada salah ucapan dari penutur yang kurang berkenan

3) Ilokusi menyindir berisi tentang sindiran yang ditujukan kepada pendengar berkaitan dengan bahasa Indonesia yang digunakan dalam menyebut sayursayuran serta sindiran karena realita masyarakat yang sulit untuk diajak ke masjid sedangkan ke mall justru lebih giat.

e. Ilokusi Deklaratif

1) Ilokusi melarang berisi tentang larangan kepada panitia untuk tidak meminta sedekah kepada pendengar sebelum ada komando dari kiayi serta 
larangan untu tidak mencari untung dari acara pengajian.

3. Tindak Tutur Perlokusi, antara lain:

1) Tindak tutur perlokusi melakukan tindakan berisi tentang tuturan yang menimbulkan efek pendengar untuk melakukan suatu tindakan. Tindakan tersebut antara lain tindakan untuk mengambil seorang anak yang bermain di atas panggung, tindakan yang dilakukan pak camat dalam memberikan sumbangsih serta tindakan pendengar untuk memberikan buah tangan untuk kiai.

2) Tindak tutur perlokusi perasaan marah berisi tentang perasaan pendengar yang merasa marah ketika penutur mengatakan tidak ada yang lebih cantik daripada Lady Diana.

Tindak tutur perlokusi perasaan senang berisi tentang perasaan pendengar yang merasa senang ketika mendengar pujian dari penutur. Pujian tersebut ialah ketika seorang anak yang dikatakan cantik seperti ibunya.

\section{DAFTAR PUSTAKA}

Arikunto, Suharsimi. 2010. Prosedur Penelitian Suatu Pendekatan Praktik. Rineka Cipta: Jakarta.

Chaer, Abdul. 2007. Linguistik Umum. PT Rineka Cipta: Jakarta.

Chaer, Abdul. 2013. Pengantar Semantik Bahasa Indoneia. Rineka Cipta: Jakarta.

Rani, Abdul dan Bustanul Arifin, dkk. 2004. Analisis Wacana. Bayumedia Publishing: Malang.

Rahayuningsih, Eka. 2013. Tindak Tutur Representatif dalam Ceramah $\mathrm{KH}$. Anwar Zahid. Skripsi. Jember: Program Strata 1 Universitas Jember.

Rachmawati, Ega Nanda Safitri. 2016. Bentuk Tindak Tutur Penyandang Tunagrahita Kelas VIII SMPLB di SLB-C Kemala Bhayangkari 2 Gresik. Skripsi. Surabaya: Program Strata 1 Universitas Negeri Surabaya.

Yule, George. 2009. Pragmatik. Pustaka Pelajar: Yogyakarta. 